\title{
GROWTH PROMOTING EFFECTS OF VERMIWASH AND PANCHAGAVYA ON DOLICHUS LABLAB UNDER FIELD EXPERIMENTAL CONDITIONS
}

\author{
V.N. Maheswari' ${ }^{1}$, M.P. Srikumaran ${ }^{1}$, G.S. Rekha ${ }^{1}$, D. Elumalai ${ }^{2}$ and P.K. Kaleena ${ }^{1 *}$ \\ ${ }^{1}$ Department of Zoology, Presidency College (Autonomous), Chennai-600005, Tamil Nadu, India \\ ${ }^{2}$ Department of Zoology, Pachaiyappas College for Men, Kanchipuram- 631501, Tamil Nadu, India
}

*corresponding author's email: drpkklab@gmail.com, pkkaleena@yahoo.co.in

\begin{abstract}
The present study explores the growth promoting effects of vermiwash and panchagavya on Dolichus lablab. Vermiwash was obtained from the vermicomposting unit and panchagavya was prepared using cow products such as milk, curd, urine, ghee and dung. Different concentrations of vermiwash and panchagavya $(5: 2 \%, 10: 3 \%$ and $15: 4 \%)$ were applied to the bean plants once in every week for 90 days. The exomorphological characters such as shoot length, internode length, diameter of the internode, number of leaves, leaf surface area and chlorophyll content were recorded prior to every treatment in all the groups. Interestingly, 10:3\% vermiwash and panchagavya treated lablab beans showed better growth promoting effects than the other plants. Thus, the results of the present study clearly suggest that $10: 3 \%$ vermiwash and panchagavya could be used as effective foliar spray in the near future.
\end{abstract}

Keywords: Vermiwash; Panchagavya; Foliar sprays; Lablab bean.

\section{Introduction}

The compost prepared through the application of worms usually red wiggler (Eisenia fetida), African night crawler (Eudrilus eugeniae) and other earthworms is known as vermicompost and the technology of using such local species of earthworms for crop production or composting is called vermitech (Ismail, 2005). Vermicompost is usually a finely divided peat-like material with excellent structure, porosity, aeration, drainage and moisture holding capacity. Vermiwash is a liquid fertilizer collected after the passage of water through a column of worm activation. It is a collection of excretory and secretory products of earthworms along with major micronutrients of the soil and soil organic molecules (Ansari, 2008). Recently, many studies have reported that vermiwash as foliar spray is effective. Different doses of vermiwash and vermicompost were used to study their effect on the growth and flowering of Zinnia sp. Among them, 20\% vermicompost and vermiwash showed maximum positive effects than the other tested concentrations (Chattopadhyay, 2014).

Vermiwash spray has significantly enhanced the growth (plant height and number of leaves) and yield (number of flowers and fruits per plant) parameters of Solanum melongena. Also, flowering and fruiting ratio was increased (Sundararasu and Jeyasankar, 2014). Vermiwash treatment elevated the levels of total macronutrients (N, P, K and C) and micronutrients ( $\mathrm{Fe}, \mathrm{Cu}, \mathrm{Mg}$ and $\mathrm{Zn}$ ). In addition, vermiwash treated Capsicum frutescens showed increased root and shoot length after 30 days. The number of leaves was also found to be increased than the vermiwash untreated plants (Varghese and Prabha, 2014). Recently, Chavan et al. (2015) have observed significant increase in the growth of cluster bean after treatment with vermicompost fertilizer.

Panchagavya is an organic product blended with five different cow products, commonly applied to crop plant in organic farming. It acts as growth promoter and immunity booster and also restricts the incidence of common diseases (Vallimayil and Sekar, 2012). Panchagavya is also known to contain growth regulatory substances such as IAA, GA, and cytokinin. Panchagavya was applied on southern sunnhemp mosaic virus infected plants as foliar spray; panchagavya treated plants showed better growth and lesser viral intensity than the control sunnhemp plants (Vallimayil and Sekar, 2012). Significant improvement in the growth and nutrient content of Vitis vinifera was observed using panchagavya along with microbial fertigation (Geetha and Aruna, 2013). Interestingly, panchagavya had the highest population of total bacteria, actinomycetes, phosphate solubilizers, fluorescent pseudomonads and nitrifiers. In addition, dehydrogenase activity and microbial biomass carbon were also found to be higher in panchagavya 
(Amalraj et al., 2013). Jandaik and Sharma (2016) have recently reported the antifungal activity of panchagavya against three pathogens Rhizoctonia solani, Fusarium oxysporium and Sclerotium rolfsii. In their study, panchagavya exhibited antifungal activity against all the three pathogens at three different concentrations i.e 5, 10 and $15 \%$. However, $15 \%$ concentration was most effective and exhibited $82 \%$ of inhibition against $F$. oxysporium. With this background, the present study was aimed to evaluate the growth promoting effects of vermiwash and panchagavya on lablab beans under field conditions for 90 days.

\section{Materials and Methods}

\section{Crop and Field Selection}

The farm land was selected for the cultivation of Dolichus lablab near Vayanallur (70 to $255 \mathrm{Sq}$. Ft.) on the suburbs of Chennai. The field was cleaned well and ploughed uniformly. It also had adequate facilities to carry out the experiments.

\section{Preparation of Vermiwash and Panchagavya}

Vermicomposting unit $(3 \times 2 \times 5$ feet, lbh) was set up with layers of gravel, sand, garden soil, cowdung parts and sufficient water for the growth of Eudrilus eugeniae as they produce compost quicker and multiply rapidly. About $1 \mathrm{~kg}$ of this species accounting 200 worms was added to the container. The water outlet tap was fixed at the bottom in order to collect the vermiwash after 45 days of composting. Panchagavya was prepared from cow products viz. cow milk (5 L), ghee (2 L), curd (2 kg), cow urine (5 L) and cow dung $(5 \mathrm{~kg})$; these ingredients were mixed together along with $15 \mathrm{~kg}$ of jaggery in a circular container. The mixture was added with $15 \mathrm{~L}$ of water and kept as such for 30 days. Fermentation took place by making the mixture to a fine concentrate giving out the sweet odour (Ismail, 2005).

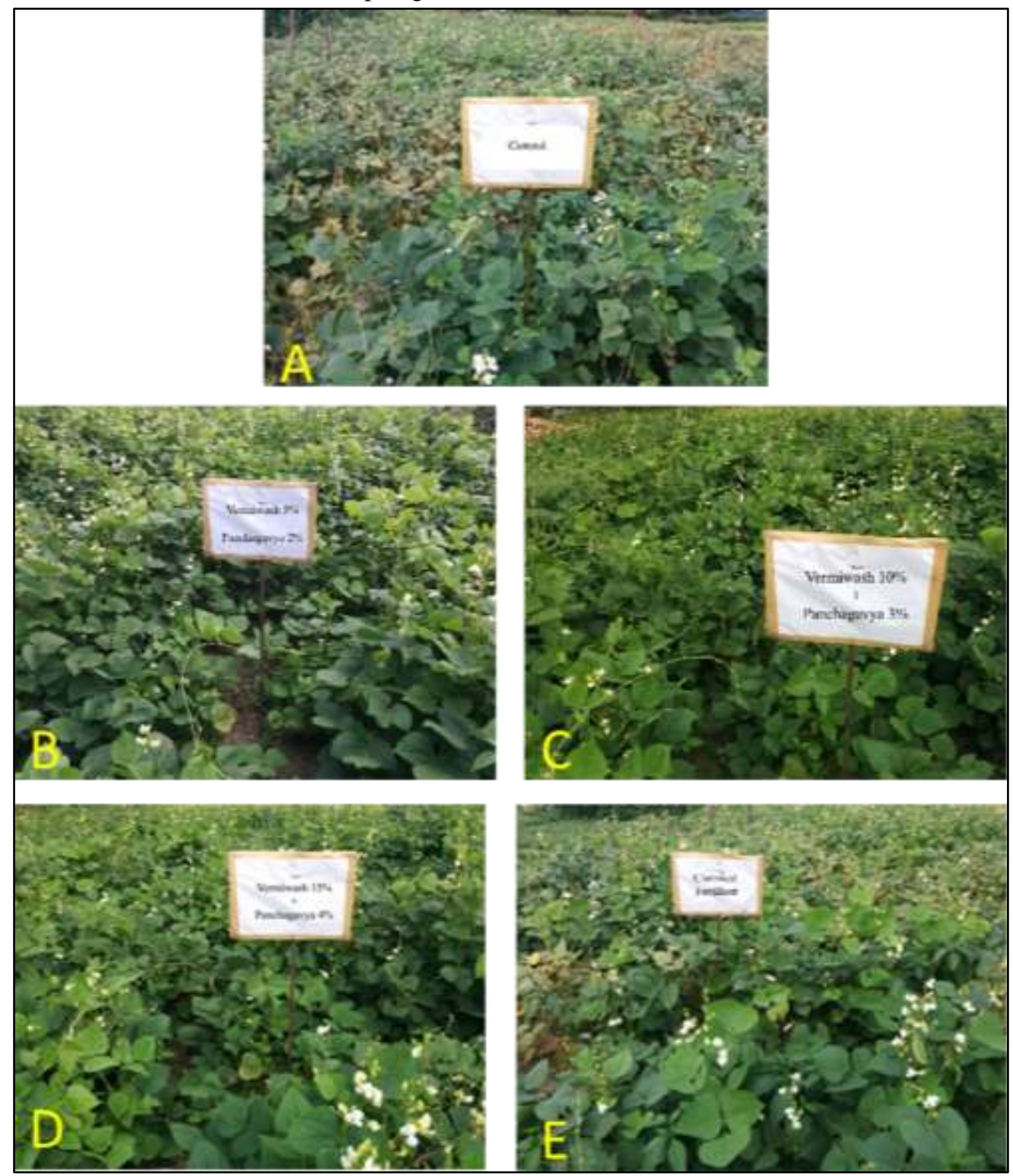

Fig. 1. Plant growth parameters - Field treatments - Exo morphological characters of Dolichus lablab A. Control; B. Vermiwash 5\% panchagavya 2\%; C. Vermiwash $10 \%$ panchagavya $3 \%$; D. Vermiwash $15 \%$ panchagavya $4 \%$; E. Chemical fertilizer. 


\section{Field Experimental Condition}

Lablab seeds were bought from the Tamil Nadu Agricultural University, Coimbatore. The seeds were sown at regular intervals of 1 foot from each plant and were allowed to germinate. Initially, the plants were grouped into five categories. Group 1 was control plants and group 2 was chemical treatment group. Groups 3, 4 and 5 were treated with 5:2, 10:3 and 15:4\% vermiwash and panchagavya, respectively (Fig. 1-2; Table 1). These organic foliar sprays were sprayed at regular intervals i.e. once in every week for 90 days. This was done at early morning or late evening; so that sprays were not dried up directly under sun light.

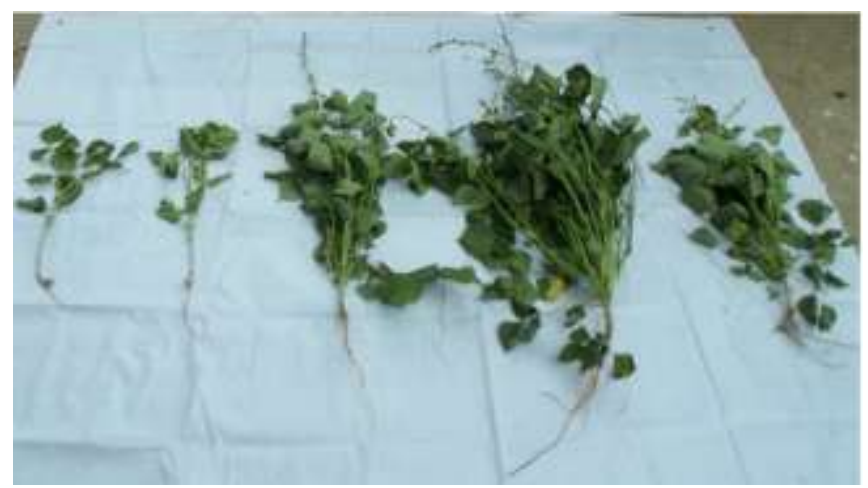

Fig. 2: Exo-morphological characters of Dolichus lablab after different treatments.

Table 1: Various concentrations of vermiwash, panchagavya and plant growth regulators used for the study

\begin{tabular}{|c|c|c|c|}
\hline $\begin{array}{l}\text { S. } \\
\text { N. }\end{array}$ & Treatment & $\begin{array}{l}\text { Organic plant } \\
\text { growth } \\
\text { promoters } \\
\text { (PGP) }\end{array}$ & $\begin{array}{l}\text { Concentration } \\
(\text { PGP + } \\
\text { water })\end{array}$ \\
\hline 1 & Control & - & Water \\
\hline 2 & $\begin{array}{l}\text { Vermiwash } \\
5 \% \\
\text { panchagavya } \\
2 \%\end{array}$ & $\begin{array}{l}\text { Vermiwash } \\
\text { panchagavya }\end{array}$ & $\begin{array}{l}50+950 \mathrm{~mL} \\
20+980 \mathrm{~mL}\end{array}$ \\
\hline 3 & $\begin{array}{l}\text { Vermiwash } \\
10 \% \\
\text { panchagavya } \\
3 \%\end{array}$ & $\begin{array}{l}\text { Vermiwash } \\
\text { panchagavya }\end{array}$ & $\begin{array}{l}100+900 \mathrm{~mL} \\
30+970 \mathrm{~mL}\end{array}$ \\
\hline 4 & $\begin{array}{l}\text { Vermiwash } \\
15 \% \\
\text { panchagavya } \\
4 \%\end{array}$ & $\begin{array}{l}\text { Vermiwash } \\
\text { panchagavya }\end{array}$ & $\begin{array}{l}150+850 \mathrm{~mL} \\
40+960 \mathrm{~mL}\end{array}$ \\
\hline 5 & $\begin{array}{l}\text { Chemical } \\
\text { fertilizer }\end{array}$ & Virux & $\begin{array}{l}50 \mathrm{~mL}+20 \\
\text { litre }\end{array}$ \\
\hline
\end{tabular}

\section{Analysis of Exo-Morphological Characters}

At the end of every week of spray and at zero hour, i.e. just before giving the spray application, the exo-morphological characters such as height of the plant, length of the internode, diameter of the internode, number of leaves and leaf surface area were recorded in vermiwash and panchagavya treated plants for 90 days and the results were compared with that of control and chemical treatment groups.

\section{Estimation of Chlorophyll}

Chlorophyll- $\mathrm{a}$ and $\mathrm{b}$ were determined according to the method of Arnon (1949). Fresh leaves (0.2 g) were taken and extracted overnight with $80 \%$ acetone at $-4{ }^{\circ} \mathrm{C}$. The extract was centrifuged at $10000 \mathrm{x} \mathrm{g}$ for $5 \mathrm{~min}$. The absorbance of the supernatant was read at 645, 663 and 480 nm using UV-visible spectrophotometer (Hitachi-220, Japan). The Chlorophyll- $a$ and $b$ were calculated by the following formulae:

Chl a (mg g ${ }^{-1}$ f.wt.) $=[12.7(\mathrm{OD}$ 663)-2.69(OD 645) $\times \mathrm{V} / 1000 \times \mathrm{W}]$

Chl b (mg g ${ }^{-1}$ f.wt. $)=[22.9(\mathrm{OD}$ 645)-4.68(OD 663) $\times \mathrm{V} / 1000 \times \mathrm{W}]$

Total Chl $=\mathrm{Chl} \mathrm{a}+\mathrm{Chl} \mathrm{b}$

Where,

$\mathrm{V}=$ volume of the sample

$\mathrm{W}=$ weight of fresh tissue

\section{Statistical Analysis}

The data were subjected to One-way Analysis of Variance (ANOVA) to determine the significance of individual differences at $p>0.001$ level. Significant means were compared by the Duncan's multiple range test. All statistical analyses were carried out using SPSS statistical software package (SPSS, Version 10.0, Chicago, USA).

\section{Results}

\section{Analysis of Exo-Morphological Characters}

\section{Shoot length}

The shoot length was found to be increased in chemical fertilizer as well as vermiwash and panchagavya treated plants compared to the control group. However, increased shoot length was found in vermiwash and panchagavya treated plants than the chemical fertilizer treated group (Fig. 3 ). In case of vermiwash and panchagavya treatment, better growth effect was observed in 10:3\% vermiwash and panchagavya treated plants; the shoot length was $60.35 \mathrm{~cm}$ after 90 days.

\section{Length of the Internode}

Internode length was increased in chemical fertilizer as well as vermiwash and panchagavya treated plants than the control plants; but, increased length was observed in vermiwash and panchagavya treated groups than the chemical fertilizer treated plants (Fig. 4). Better growth effect was found in 10:3\% vermiwash and panchagavya treated plants. The internode length was increased almost three fold after 90 days. 


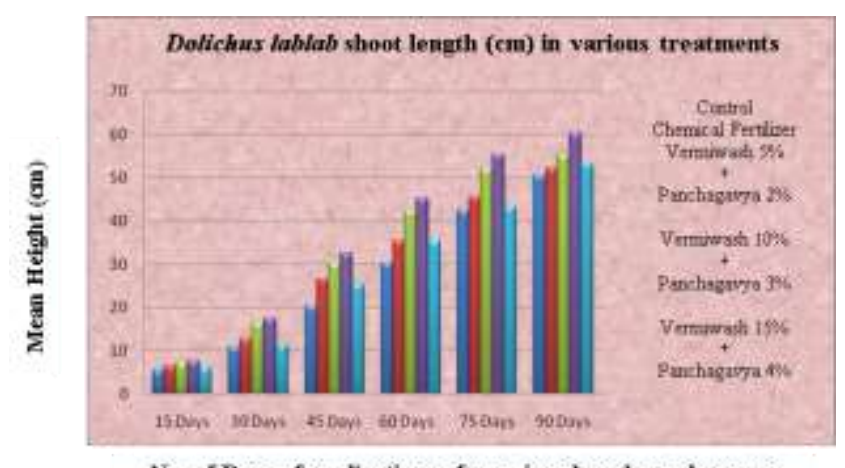

Fig. 3: Effect of panchagavya and vermiwash on shoot length of Dolichus lablab.

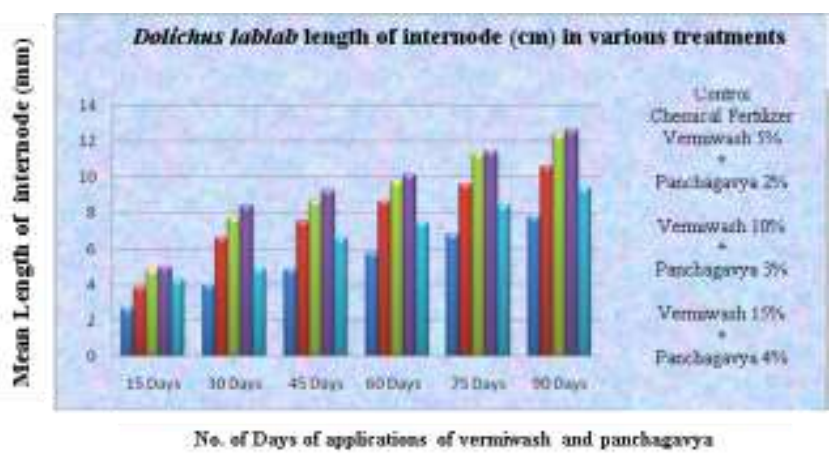

Fig. 4: Effect of panchagavya and vermiwash on internode length of Dolichus lablab.

\section{Diameter of the Internode}

The diameter of the internode was found to be increased in chemical fertilizer as well as vermiwash and panchagavya treated groups than the control. Interestingly, better effect was found in 10:3\% vermiwash and panchagavya treated group than the other plants (Fig. 5). The diameter of the internode was increased to $7.64 \mathrm{~mm}$ after 90 days.

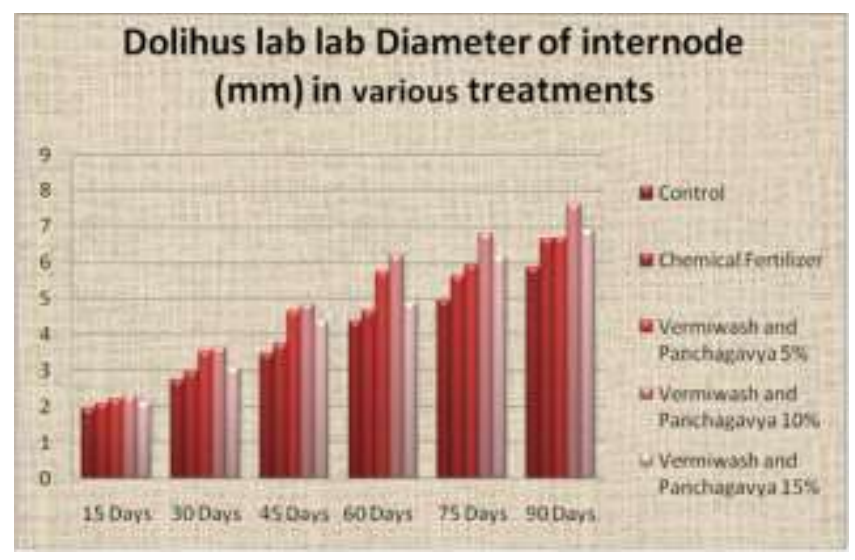

Fig. 5: Effect of panchagavya and vermiwash on diameter of internode of Dolichus lablab.

\section{Number of Leaves}

Number of leaves was found to be increased in chemical fertilizer as well as vermiwash and panchagavya treated groups than the control plants. However, better effect was noticed in 10:3\% vermiwash and panchagavya treated plants (Fig. 6). After 90 days, the number of leaves was increased to 42 from 11 .

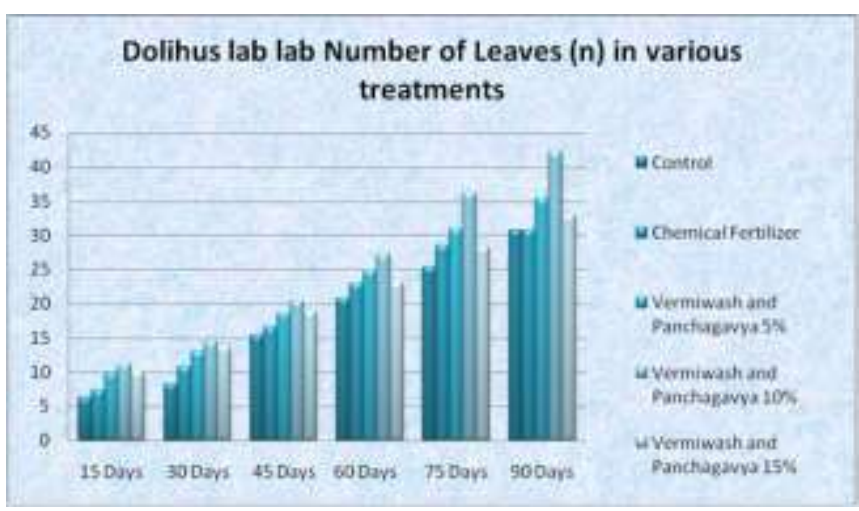

Fig. 6: Effect of panchagavya and vermiwash on number of leaves of Dolichus lablab.

\section{Leaf Surface Area}

Increased leaf surface area was observed in chemical fertilizer as well as vermiwash and panchagavya treated groups than the normal control plants. Better growth effect was observed in 10:3\% vermiwash and panchagavya treated plants (Fig. 7). Interestingly, they showed four fold increment of leaf surface area after 90 days.

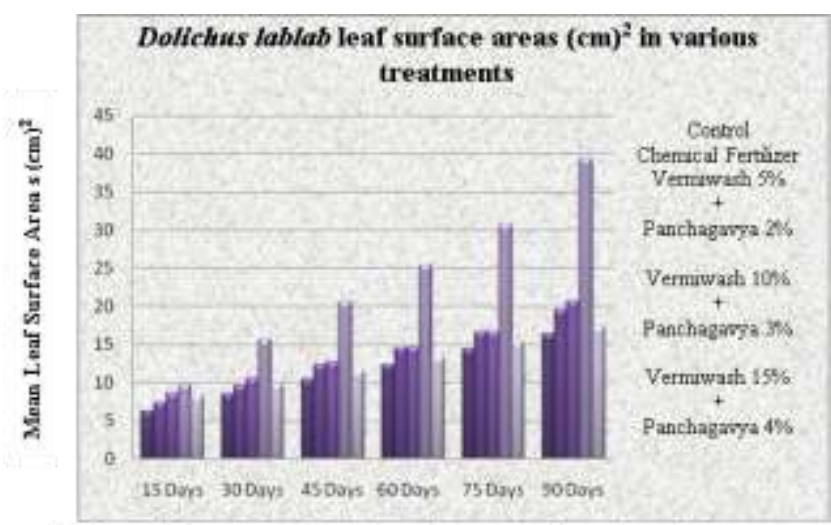

No. of Days of applications of vermiwash and panchagavya

Fig. 7: Effect of panchagavya and vermiwash on the leaf surface area of Dolichus lablab.

\section{Estimation of Chlorophyll}

Increased chlorophyll content was observed in vermiwash and panchagavya treated plants than the control and chemical fertilizer treated groups (Table 2). Interestingly, in this study, 10:3\% vermiwash and panchagavya treated plants showed $0.81 \mathrm{mg} / \mathrm{g}$ F.wt of Chlorophyll-a, and 0.75 $\mathrm{mg} / \mathrm{g}$ F.wt of Chlorophyll- $b$, respectively. 
Table 2: Estimation of chlorophyll content of Dolichus lablab under different treatment conditions

\begin{tabular}{|l|l|l|l|}
\hline Pigment & Control plants & $\begin{array}{l}\text { Chemical fertilizer } \\
\text { treated plants }\end{array}$ & $\begin{array}{l}\text { 10:3\% vermiwash } \\
\text { and panchagavya } \\
\text { treated plants }\end{array}$ \\
\hline $\begin{array}{l}\text { Chlorophyll-a } \\
\text { (mg/g F.wt) }\end{array}$ & 0.50 & 0.59 & 0.81 \\
\hline $\begin{array}{l}\text { Chlorophyll-b } \\
\text { (mg/g F.wt) }\end{array}$ & 0.49 & 0.38 & 0.75 \\
\hline $\begin{array}{l}\text { Total chlorophyll } \\
\text { (mg/g F.wt) }\end{array}$ & 0.98 & 0.92 & 1.7 \\
\hline
\end{tabular}

\section{Discussion}

Organic farming alone could serve as the holistic approach towards achieving sustainable agriculture as it is ecofriendly and ensures the conservation of resource for the future. Earthworms and their vermicompost work like miracle growth promoter and are nutritionally better to the conventional compost and chemical fertilizers. Earthworm and its vermicast and vermiwash are scientifically proving as both growth promoters and protectors for crop plants. To the best our knowledge, this may be the first study in which both vermiwash and panchagavya were used as foliar spray to evaluate their growth promoting effects on lablab beans. In this study, three different concentrations of vermiwash and panchagavya $(5: 2 \%, 10: 3 \%$ and $15: 4 \%)$ were tested on lablab beans. Of these, 10:3\% vermiwash and panchagavya treated plants showed better growth promoting effects in terms of exo-morphological characters such as shoot length, internode length, diameter of the internode, number of leaves and leaf surface area. On the other hand, 5:2\% and 15:4\% vermiwash and panchagavya treated plants showed better effects than the chemical fertilizer treated group.

These results were found to be consistent with the studies of Rajan and Murugesan (2012) and Nath and Singh (2012); however, they have observed the growth promoting effects using vermiwash only. In another study, $15 \%$ vermiwash exhibited better growth promoting effects on Abelmoschus esculentus (Elumalai et al., 2013). Vermiwash treated Capsicum frutescens showed increased root, shoot length and number of leaves after 30 days than the vermiwash untreated plants (Varghese and Prabha, 2014). Vermiwash along with gibberellic acid was used to bring about seed germination and seedling growth in Hibiscus sabdariffa and Phaseolus vulgaris (Fathima and Malathy, 2014). The enhanced growth may be due to the presence of growth regulatory substances such as IAA, GA, cytokinin, essential plant nutrients, effective microorganisms and biofertilizers like Acetobacter, Azosprillum and Phosphobacterium present in the panchagavya and vermiwash (Esakkiammal et al., 2015; Somasundram et al., 2004). In addition, panchagavya has also been reported to contain bacteria producing plant growth promoting substances as well as bacteria having biological activities. Presence of such beneficial microbial biomass resulted in enhanced seed germination, seedling length and seed vigor in wheat. Thus, it is obvious from these results that vermiwash promotes the growth of lablab beans radically along with panchagavya.

\section{Conclusion}

In this study, better growth effects were observed in vermiwash and panchagavya treated plants than the chemical fertilizer and control lablab plants. Interestingly, remarkable growth promoting effects were recorded only in 10:3\% vermiwash and panchagavya treated group. Thus, the results obtained from the field experimental conditions suggest that $10: 3 \%$ vermiwash and panchagavya could be explored as effective foliar spray for the better growth of vegetable crops in the near future.

\section{Acknowledgements}

The authors would like to extend their grateful thanks to the Principal, Presidency College, Chennai, Tamil Nadu for providing the facilities to carry out this research work.

\section{References}

Amalraj ELD, Kumar GP, Ahmed SMH, Abdul R and Kishore N (2013). Microbiological analysis of Panchagavya, vermicompost, and FYM and their effect on plant growth promotion of pigeon pea (Cajanus cajan L.) in India. Organic Agriculture 3(1): 23-29. DOI: 10.1007/s13165013-0042-2

Ansari AA (2008) Effect of vermicompost and vermiwash on the productivity of spinach Spinacia oleracea, onion Allium cepa and potato Solanum tuberosum. World J. Agri. Sci. 4(5): 554-557.

Arnon DI (1949) Copper enzymes in isolated chloroplasts. Polyphenoloxidase in Beta vulgaris. Plant Physiol. 24: 115. DOI: $10.1104 / p p .24 .1 .1$

Chattopadhyay A (2014) Effect of vermiwash and vermicompost on an ornamental flower, Zinnia sp. J. Horticulture 1: 112. DOI: $10.4172 / 2376-0354.1000112$

Chavan BL, Vedpathak MM and Pirgonde BR (2015) Effects of organic and chemical fertilizers on cluster bean (Cyamopsis tetragonolobus). European J. Exp. Biol. 5(1): 34-38.

Elumalai D, Kaleena PK, Fathima M and Hemavathi M (2013) Influence of vermiwash and plant growth regulators on the 
exomorphological characters of Abelmoschus esculentus (Linn.) Moench. African J. Basic Appl. Sci. 5(2): 82-90.

Esakkiammal B, Esaivani C, Vasanthi K, LakshmiBai L and Shanthi Preya N (2015) Microbial diversity of vermicompost and veriwash prepared from Eudrilus euginae. Int. J. Curr. Microbiol. App. Sci. 4(9): 873-883.

Fathima M and Malathy S (2014) Studies on growth promoting effects of vermiwash on the germination of vegetable crops. Int. J. Curr. Microbiol. App. Sci. 3(6): 564-570.

Geetha S and Aruna D (2013) Effect of microbial fertigation and panchagavya on the growth of Vitis vinifera graftings. Int. J. Bioscience Res. 2: 1-6.

Ismail SA (2005) The Earthworm Book. Other India Press, Apusa, Goa.

Jandaik S and Sharma V (2016) Antifungal potential of panchagavya against soil borne fungal pathogens associated with Capsicum nurseries. Int. Invention J. Agri. Soil Sci. 4(2): 22-26.

Nath G and Singh K (2012) Effect of vermiwash of different vermicomposts on the kharif crops. J. Central European Agri. 13(2): 379-402. DOI: 10.5513/jcea01/13.2.1063
Rajan MR and Murugesan P (2012) Influence of vermiwash on germination and growth of cow pea Vigna ungiculata and Rice Oryza sativa. IOSR J. Pharmacy 2(6): 31-34. DOI: $10.9790 / 3013-26403134$

Somasundram E, Sankaran N and Thigarajan TM (2004). Modified panchagavya for better yield. www.Hinud.com/ seta/2004/02/12.

Sundararasu K and Jeyasankar A (2014) Effect of vermiwash on growth and yield of brinjal, Solanum melongena (egg plant or aubergine). Asian J. Sci. Tech. 5(3): 171-173.

Vallimayil J and Sekar R (2012) Investigation on the effect of panchagavya on sounthern sunnhemp mosaic virus (SSMV) infected plant systems. Global J. Environ. Res. 6(2): 75-79.

Varghese SM and Prabha ML (2014) Biochemical Characterization of Vermiwash and its Effect on Growth of Capsicum frutescens. Malaya J. Biosciences 1(2): 8691. 